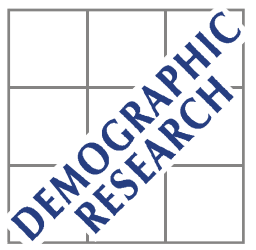

Demographic Research a free, expedited, online journal of peer-reviewed research and commentary in the population sciences published by the Max Planck Institute for Demographic Research Doberaner Strasse 114 D D-18057 Rostock · GERMANY www.demographic-research.org

DEMOGRAPHIC RESEARCH

VOLUME 7, ARTICLE 7, PAGES 343-364

PUBLISHED 14 AUGUST 2002

www.demographic-research.org/Volumes/Vol7/7/

DOI: $10.4054 /$ DemRes.2002.7.7

Descriptive Findings

\title{
Children's experience of family disruption and family formation: Evidence from 16 FFS countries
}

\section{Gunnar Andersson}

(C) 2002 Max-Planck-Gesellschaft. 


\section{Table of Contents}

1 Introduction $\quad 344$

2 Data and methods $\quad 345$

3 Results 348

3a Distribution of births 348

$3 \mathrm{~b} \quad$ Children's experience of family formation $\quad 349$

$3 c \quad$ Children's experience of family dissolution 351

3d A summary of children's experience of living 354

3e Children's experience of family reconstitution 355

3f A summary measure of children's experience of 357

$\begin{array}{lll}4 & \text { Conclusions } & 359\end{array}$

$\begin{array}{ll}\text { Acknowledgments } & 360\end{array}$

$\begin{array}{ll}\text { Notes } & 361\end{array}$

$\begin{array}{ll}\text { References } & 362\end{array}$ 
Descriptive Findings

\title{
Children's experience of family disruption and family formation: Evidence from 16 FFS countries ${ }^{1}$
}

\author{
Gunnar Andersson ${ }^{2}$
}

\begin{abstract}
In this paper, we present a number of descriptive measures on children's experience of family disruption and family formation. We use data from the Fertility and Family Surveys of 15 European countries and corresponding data from the USA in order to find out what kind of family circumstances children are born into and what experience they subsequently have of various family-transformation events of their mothers. Our presentation reveals some similarities but also striking differences in the family-demographic experience of children in different countries. The USA stands out as one extreme case with its very high proportion of children born to a lone mother, with a higher probability of children who experience a union disruption of their parents than anywhere else, and with many children having the experience of living in a stepfamily. Italy stands out at the other end of the scale. Practically all children here are born to a married mother and very few of them experience the dissolution of their parents' union before they turn 15 .
\end{abstract}

1 Paper presented at the XXIVth IUSSP General Population Conference in Salvador, Brazil, 18-24 August 2001.

2 Max-Planck-Institute for Demographic Research, Doberaner Str. 114, 18057 Rostock, Germany;

Tel. +49 381 / 2081 185, Fax +49 381 / 2081 279. Email: andersson@demogr.mpg.de 


\section{Introduction}

The last three decades have witnessed an upsurge in research on various aspects of the family dynamics of people in developed countries. An increased attention to changes in patterns of family formation and family dissolution, and to consequences of such changes, follows the observed increase in the variation of how people tend to organize their family lives. Attention has, for example, been given to the fact that people in many European countries today, often live together in unions without being married (Murphy 2000, Prinz 1995, Toulemon 1997). Consequently, the marital status of people is far from sufficient if one wants to get an accurate picture of their family status (Bumpass and Raley 1995).

A starting point for our study is that we think there is still a need for more and better descriptions of the present state of family-demographic affairs in contemporary European countries. It is indeed important to first know exactly how the situation looks before one tries to explain it, and it is particularly important to get a better picture of various differences and similarities in demographic behavior between the different countries in Europe. In some cases, the perception of a very volatile situation in the domains of family-demography might turn out to be slightly exaggerated. Perhaps, the situation is not always as dynamic as one might think it is when one reads research material stemming from, for example, the US.

There are not that many large-scale cross-country comparisons available in this field of research. However, Kiernan $(2000,2001)$ provides such comparisons when she focuses on the status of unions in Western Europe and the context of childbearing there. Klijzing and Macura (1997) provide another example of an overview of the family context for childbearing in Europe. Finally, Heuveline and Timberlake (2000) and Heuveline, Timberlake, and Furstenberg (2001) present a set of family-demographic cross-country comparisons when examining the experiences of different living arrangements and family types of children in a wide range of European countries. The previous lack of studies that describe the familydemographic situation from the point of view of children is otherwise regrettable, since researchers' attention on processes such as divorce is often motivated by the concern for children involved. When studying the family dynamics from children's perspective, it is of course particularly important to be able to get a picture of their parents' actual living arrangements rather than just that of their marital status (Bumpass and Raley 1995, Bumpass and Hsien-Hen 2000).

In our study, we present a number of descriptive measures on children's experience of various family-demographic events. Our study is a cross-country comparison and, like the comparative studies we referred to above, it is based on data derived from the last round of European Fertility and Family Surveys (FFS). 
We use data as reported by children's mothers from 16 countries - from countries in Western and Eastern Europe and from the USA - in order to estimate to what extent children experience events like a union disruption of their parents or a union formation of their lone mother. We present separate calculations for children born to a lone mother, children born to a cohabiting mother, and children born in marriage, so that we can depict the different family-transformation events that can occur in each type of family. For children who experience their parents' union disruption, we examine to what extent they experience the formation of a new union of their mother. In our comparison, we present results for different ages of children so that we can follow a typical child from its birth to the $15^{\text {th }}$ birthday.

\section{Data and methods}

Our presentation is based on a more extensive set of tabulations provided by Andersson and Philipov (2002). They have estimated a relatively large number of life tables over children's various experiences of different family-transformation events between ages 0 and 15. This is in addition to other sets of life tables that describe the experiences of adult men and women of various family-formation and family-dissolution events of interest. The tabulations are based on raw data gathered at the Fertility and Family Surveys that had been conducted in a large number of European countries in 1989-1997. The US National Survey of Family Growth from 1995 gives comparable data for the USA, so patterns in Europe can be compared to those that prevail on the other side of the Atlantic. For each country, we present the cumulative percent of children who have ever experienced a certain familydemographic event at selected ages so that we can use it in a broad cross-country comparison. Our life-table estimates are based on the children's mothers' reports on various union-formation and union-dissolution events. We do not use the information reported by fathers since large segments of children's lives are missing in their reports. In most cases, children live with their mother if they don't live with both parents, so mother's reports give a better coverage of the actual living arrangements of their children. In our calculation of life tables that depict children's experience of family-formation events of their lone mother (presented in Sections $3 \mathrm{~b}$ and $3 \mathrm{e}$ ), we censor an observation if a child moves away from its mother in order to live with the father or on its own. We would then have no information on further changes in the living arrangements of that child. Such censoring is quite rare since practically all reported childhood time refer to time lived with the mother (Note 1). Our life tables that depict the family-dissolution events of children living with their two parents (presented in Sections 3c and 3d) cover cases when parents move apart, 
but also cases when the father dies or the child moves away from its parents. We censor any observation at the rare event of a death of a child. In addition, all observations are censored at a child's $15^{\text {th }}$ birthday or at the age the child had at the time of the mother's interview.

Our life tables are based on the idea of a synthetic cohort. They are calculated from reported events of a specific kind and exposures to that event (for children at different ages) during a period of six years immediately before each survey date so that they describe the patterns of family-demographic affairs during that calendar period (Note 2). As any synthetic-cohort measure, our life tables thus give information on the demographic patterns that would arise if the calculated agespecific transition rates prevail during a generation or so. We have calculated life tables for the following countries (Note 3): Sweden, Norway, Finland, France, the USA, Austria, Germany, Flanders (Note 4), Italy, Spain, the Czech Republic, Hungary, Slovenia, Latvia, Lithuania, and Poland. East and West Germany are treated separately. For East Germany (referred to as the former GDR), we use the six-year term immediately before the political turnaround in November 1989 as our study period. Before calculating the various life-table measures that we present here, we needed to perform a considerable amount of data cleaning. The raw data for Austria and Germany, just to mention one example, contained a large number of observations with missing dates of union formation and union dissolution of respondents so we had to exclude them from our calculations. Table 1 contains the total number of female respondents, mothers, and all children of these respondents that, for each country, remain in our data set after our cleaning procedures. Female respondents come from the populations "at reproductive ages" but the upper age limit of these respondents varies slightly between countries (Note 5). In our calculations, we have subsequently used all information that refers to the experience of children aged 0-15 years during the calendar periods upon which we base our synthetic cohorts. We have applied weights in our calculations of life-table estimates for France and the US since the sampling procedures in these countries were performed in a way that were dependent on the outcomes we want to study.

As a complement to our presentation of life tables, we derive a number of summary measures of children's family experiences, namely the percentages of children who are born into different family types (Section 3a), and the proportions of children who live in different family types (Section 3f). These are again calculated from information relating to the six-year period we cover. For a more detailed description of the data and our system of life-table descriptions, see Andersson and Philipov (2002). 
Table 1: $\quad$ Number of female respondents, mothers, and children of respondents, by country

\begin{tabular}{|c|c|c|c|c|c|c|}
\hline & country & women & mothers & children & $\begin{array}{l}\text { ages of } \\
\text { respondents }\end{array}$ & time of survey \\
\hline \multirow[t]{10}{*}{ "West" } & Sweden & 2986 & 2247 & 4638 & $23-43$ & 1992/93 \\
\hline & Norway & 3969 & 2367 & 4523 & $20-43$ & 1988/89 \\
\hline & Finland & 4040 & 2895 & 6043 & $22-51$ & $1989 / 90$ \\
\hline & France & 2930 & 2194 & 4527 & $20-49$ & 1994 \\
\hline & USA & 10510 & 6609 & 14357 & $15-44$ & 1995 \\
\hline & Austria & 4260 & 3217 & 6485 & $20-54$ & $1995 / 96$ \\
\hline & W Germany & 2743 & 1223 & 2113 & $20-39$ & 1992 \\
\hline & Flanders & 3143 & 1911 & 3602 & $20-40$ & 1991/92 \\
\hline & Italy & 4745 & 2858 & 5410 & $20-49$ & $1995 / 96$ \\
\hline & Spain & 3981 & 2450 & 4991 & $18-49$ & $1994 / 95$ \\
\hline \multirow[t]{7}{*}{ "East" } & E Germany & 2810 & 2025 & 3437 & $20-39$ & 1992 \\
\hline & Hungary & 3498 & 2622 & 4908 & $19-40$ & $1992 / 93$ \\
\hline & Czech Rep & 1719 & 1222 & 2331 & $15-44$ & 1997 \\
\hline & Slovenia & 2761 & 2116 & 3953 & $15-45$ & $1994 / 95$ \\
\hline & Latvia & 2622 & 2080 & 3787 & $18-49$ & 1995 \\
\hline & Lithuania & 2924 & 2113 & 3742 & $18-49$ & $1994 / 95$ \\
\hline & Poland & 4165 & 3184 & 6752 & $18-49$ & 1991 \\
\hline
\end{tabular}




\section{Results}

We begin with a presentation of the distribution of births over different types of families in the various countries under investigation. We then proceed with a description of the various family-transformation events that children born in different family-types experience from their birth to the month they turn 15 .

\section{3a. Distribution of births}

Table 2 contains the relative distribution of births during our period(s) of interest that were reported as occurring while the mothers were not living in a union, and while they were living with a partner in a consensual union, or in a marriage, respectively. We note that two countries stick out with an exceptionally high proportion of births to lone mothers: the USA with 17 percent of reported births and the former GDR with a figure of 18 percent. As we will see in our next table, substantial fractions of such children in the GDR soon found themselves living together with their mother and a partner of hers. We have no information on whether such a partner was their father, but other information tells us that most births to lone mothers in the GDR occurred to women living in so-called livingapart-together relationships. These were typically mothers who had not yet managed to find proper housing for themselves and their partner (Alt 2001: 89; see also Dennis 1999 for a discussion of the phenomena of lone motherhood in East Germany). Relatively high proportions of births to lone mothers, around 10 percent of newborn children, are also reported for France, Austria, Latvia, and Poland. In the rest of Europe, such events are fairly uncommon. For a few Catholic countries in Western/Southern Europe, notably Italy, Spain, and the Flemish parts of Belgium, we find that no more than 1-2 percent of reported births occur to lone mothers.

If we also have a look at the marital status of parents of newborn children, we find that children are typically born in matrimony. This is particularly the case in a number of Catholic countries in Southern and Eastern Europe. During our study period, it is only in Sweden where it is actually very common that childbearing occurs to unmarried parents living in a consensual union. Around half of all children here were born out of wedlock. For Norway, France, and Austria, we find moderately high proportions of births, around 20 percent, occurring to cohabiting but not married mothers. 
Table 2: $\quad$ Relative distribution of births (percent)

\begin{tabular}{lcccc} 
country & period & $\begin{array}{c}\text { to lone } \\
\text { mother }\end{array}$ & in marriage & $\begin{array}{c}\text { in consen- } \\
\text { sual union }\end{array}$ \\
\hline Sweden & $(1987-93)$ & 5 & 51 & 45 \\
Norway & $(1983-89)$ & 7 & 71 & 22 \\
Finland & $(1983-89)$ & 3 & 85 & 13 \\
France & $(1988-94)$ & 10 & 68 & 23 \\
USA & $(1989-95)$ & 17 & 72 & 11 \\
Austria & $(1990-96)$ & 10 & 70 & 19 \\
W Germany & $(1986-92)$ & 6 & 83 & 11 \\
Flanders & $(1985-92)$ & 1 & 94 & 4 \\
Italy & $(1990-95)$ & 2 & 94 & 4 \\
Spain & $(1989-95)$ & 2 & 93 & 4 \\
GDR & $(1984-89)$ & 18 & 67 & 15 \\
Hungary & $(1988-93)$ & 3 & 90 & 6 \\
Czech Rep & $(1992-97)$ & 4 & 89 & 7 \\
Slovenia & $(1989-95)$ & 6 & 78 & 16 \\
Latvia & $(1989-95)$ & 11 & 79 & 11 \\
Lithuania & $(1989-95)$ & 5 & 93 & 2 \\
Poland & $(1986-91)$ & 9 & 89 & 2 \\
\hline
\end{tabular}

\section{3b. Children's experience of family formation}

In Table 3, we describe what happens to children born to a lone mother in the various countries. We report the proportions of such children who are estimated to live with their mother and a partner of hers, being unmarried or not, by their exact ages 1, 3, and 9 years. For most of the countries for which we have a sufficient number of observations, we notice that the majority of children born to a lone mother end up living in a two-parent family at some point in time. But there are two clear exceptions: France and Poland. For Italy and Spain, we find a very fast process of family formation: half of the very few children born to a lone mother in these countries live in a two-parent family as soon as one year after the birth date. This indicates that union formation just took place immediately after the child was born, and most probably involved the father of the child. For these countries, we are unable to report any further figures for higher ages of children, since the number of 
observations then are so few that they do not allow for reliable estimation. A particularly fast process of family formation of lone mothers is also found in the GDR and Slovenia. The prevalence of childbearing to lone women is higher here, so we have the opportunity to obtain sufficient observations to follow their children up to higher ages. We discover that as many as 85-87 percent of them would have had the experience of living in a two-parent family when they turned nine - if the patterns observed in 1984-89/1989-95 had prevailed.

Table 3: $\quad$ Cumulative percent ever in union, by exact age of child, for children born to a lone mother

\begin{tabular}{llrrr} 
country & period & age 1 & age 3 & age 9 \\
\hline Sweden & $(1987-93)$ & 19 & 29 & 52 \\
Norway & $(1983-89)$ & 29 & 54 & -- \\
Finland & $(1983-89)$ & 25 & 39 & 64 \\
France & $(1988-94)$ & 8 & 13 & 38 \\
USA & $(1989-95)$ & 18 & 37 & 65 \\
Austria & $(1990-96)$ & 19 & 44 & 73 \\
W Germany & $(1986-92)$ & 12 & 32 & -- \\
Flanders & $(1985-92)$ & 5 & -- & -- \\
Italy & $(1990-95)$ & 48 & -- & -- \\
Spain & $(1989-95)$ & 46 & -- & -- \\
GDR & $(1984-89)$ & 37 & 63 & 87 \\
Hungary & $(1988-93)$ & 23 & 52 & -- \\
Czech Rep & $(1992-97)$ & 17 & -- & - \\
Slovenia & $(1989-95)$ & 42 & 66 & 85 \\
Latvia & $(1989-95)$ & 25 & 52 & 69 \\
Lithuania & $(1989-95)$ & 21 & 32 & -- \\
Poland & $(1986-91)$ & 17 & 25 & 32 \\
\hline
\end{tabular}

The estimates pertain to synthetic cohorts experiencing the transition rates prevailing six years prior to the survey date 


\section{3c. Children's experience of family dissolution}

Table 4 tells us what happens with the children who are born in a union, which in all countries is the dominating group of children, when it comes to their experience of any dissolution of their family of origin. The percent of such children who have ever experienced a family dissolution is reported by the exact ages 1, 3, 9, and 15 years. Two countries show up as having particularly high levels of disruptions of child families: the USA and Latvia. The USA has higher proportions of children with an experience of family dissolution than any other country; 40 percent of children born in a union there have had such an experience when they turn 15 . Sweden and the two parts of Germany also have relatively high levels of childfamily dissolution; around 30 percent of corresponding children there have such an experience before they turn 15 . At the other extreme, we find Italy. Only seven percent of children born in a union there would experience a family dissolution during childhood, if the patterns observed in 1990-95 had prevailed. Such an event is also fairly uncommon for corresponding children in Spain, Slovenia, and Poland, where the comparable figures all stand at a moderate 10 percent. Elsewhere in Europe, it is common to find a national figure of around 20 percent. A separate calculation of mean ages of the children that experience a family dissolution of their original parents (not shown here) reveals that the average age of the child at such an event is 6-8 years, no matter how high the general level of child-family disruption is in the country.

In Table 4, we did not pay any attention to the marital status of a child's parents since the child itself perhaps did not perceive this as a very important characteristic of its family. Nevertheless, the type of union a child is born into has a strong effect on the probability that it will ever experience a family dissolution since consensual unions everywhere are much less stable than marriages are. Therefore, in Table 5, we give more detail to our presentation and report the percentages of children who ever experience a family disruption during childhood for children born in a consensual union, and for those born in a marriage, separately. We ignore any subsequent transformations of consensual unions of parents into marriage so that we can depict differences in family stability by the family status at childbirth. Our tabulation reveals that children born in a marriage typically have only half the probability of experiencing a family disruption during childhood, as compared to children born in a consensual union. An excess instability of such a high magnitude is experienced by children born in consensual unions in practically every country in our study. If we again focus on differences between countries in family-disruption experiences of children, we find that the general patterns from Table 4 hold also when children born in the two types of family circumstances are 
presented separately (Table 5). In both cases, we find that the USA is the country where children are most likely to experience a family disruption before they turn 15 , closely followed by Latvia. In both cases, we also find Italy as the country where children have the lowest propensity for experiencing a family disruption. The patterns for Sweden turn out to be interesting. When children born in consensual unions and those born in marriage are treated separately, it no longer stands out as a country with particularly high levels of child-family disruptions. The relatively common experience of Swedish children of family dissolution, as indicated by Table 4, comes rather from the fact that so many children there are born to a cohabiting but not married couple.

Table 4: $\quad$ Cumulative percent ever out of union, by exact age of child, for children born in a union

\begin{tabular}{llrrrr} 
country & period & age 1 & age 3 & age 9 & age 15 \\
\hline Sweden & $(1987-93)$ & 2 & 9 & 21 & 30 \\
Norway & $(1983-89)$ & 2 & 6 & 15 & 21 \\
Finland & $(1983-89)$ & 1 & 6 & 14 & 20 \\
France & $(1988-94)$ & 2 & 6 & 16 & 23 \\
USA & $(1989-95)$ & 5 & 14 & 29 & 40 \\
Austria & $(1990-96)$ & 2 & 6 & 18 & 26 \\
W Germany & $(1986-92)$ & 2 & 6 & 16 & 29 \\
Flanders & $(1985-92)$ & 1 & 3 & 10 & 15 \\
Italy & $(1990-95)$ & 0 & 1 & 4 & 7 \\
Spain & $(1989-95)$ & 1 & 3 & 7 & 10 \\
GDR & $(1984-89)$ & 2 & 8 & 24 & 34 \\
Hungary & $(1988-93)$ & 1 & 4 & 14 & 22 \\
Czech Rep & $(1992-97)$ & 2 & 7 & 17 & 25 \\
Slovenia & $(1989-95)$ & 1 & 2 & 6 & 10 \\
Latvia & $(1989-95)$ & 5 & 13 & 28 & 38 \\
Lithuania & $(1989-95)$ & 2 & 5 & 16 & 25 \\
Poland & $(1986-91)$ & 1 & 2 & 6 & 10 \\
\hline
\end{tabular}

The estimates pertain to synthetic cohorts experiencing the transition rates prevailing six years prior to the survey date 
Table 5: $\quad$ Cumulative percent ever out of union, by exact age of child, for children born in a:

\begin{tabular}{|c|c|c|c|c|c|c|c|c|c|}
\hline \multirow[b]{2}{*}{ country } & \multirow[b]{2}{*}{ period } & \multicolumn{4}{|c|}{ consensual union } & \multicolumn{4}{|c|}{ marriage } \\
\hline & & age 1 & age 3 & age 9 & age 15 & age 1 & age 3 & age 9 & age 15 \\
\hline Sweden & (1987-93) & 4 & 13 & 27 & 38 & 1 & 5 & 15 & 24 \\
\hline Norway & (1983-89) & 8 & 18 & 30 & 36 & 1 & 4 & 12 & 18 \\
\hline Finland & (1983-89) & 4 & 19 & 35 & 39 & 1 & 4 & 11 & 17 \\
\hline France & $(1988-94)$ & 5 & 16 & 35 & 58 & 1 & 3 & 11 & 17 \\
\hline USA & (1989-95) & 18 & 39 & 64 & 78 & 3 & 10 & 24 & 35 \\
\hline Austria & $(1990-96)$ & 6 & 13 & 31 & 43 & 1 & 4 & 15 & 23 \\
\hline W Germany & $(1986-92)$ & 4 & 16 & 37 & -- & 1 & 5 & 13 & 26 \\
\hline Flanders & (1985-92) & 4 & 15 & 34 & -- & 1 & 2 & 9 & 14 \\
\hline Italy & (1990-95) & 0 & 2 & 7 & -- & 0 & 1 & 4 & 7 \\
\hline Spain & (1989-95) & 9 & 24 & -- & -- & 1 & 2 & 6 & 9 \\
\hline GDR & (1984-89) & 6 & 19 & 38 & -- & 1 & 6 & 21 & 31 \\
\hline Hungary & $(1988-93)$ & 7 & 17 & 48 & 58 & 1 & 4 & 12 & 20 \\
\hline Czech Rep & $(1992-97)$ & 9 & 27 & -- & -- & 1 & 5 & 15 & 24 \\
\hline Slovenia & (1989-95) & 3 & 8 & 14 & 19 & 0 & 1 & 5 & 8 \\
\hline Latvia & $(1989-95)$ & 16 & 36 & 58 & 69 & 3 & 10 & 24 & 34 \\
\hline Lithuania & (1989-95) & 15 & -- & -- & -- & 1 & 5 & 15 & 24 \\
\hline Poland & $(1986-91)$ & 0 & 12 & 26 & -- & 1 & 2 & 5 & 10 \\
\hline
\end{tabular}

The estimates pertain to synthetic cohorts experiencing the transition rates prevailing six years prior to the survey date 


\section{3d. A summary of children's experience of living outside the union of their parents}

Figure 1: $\quad$ Cumulative percent ever out of union, by age of child
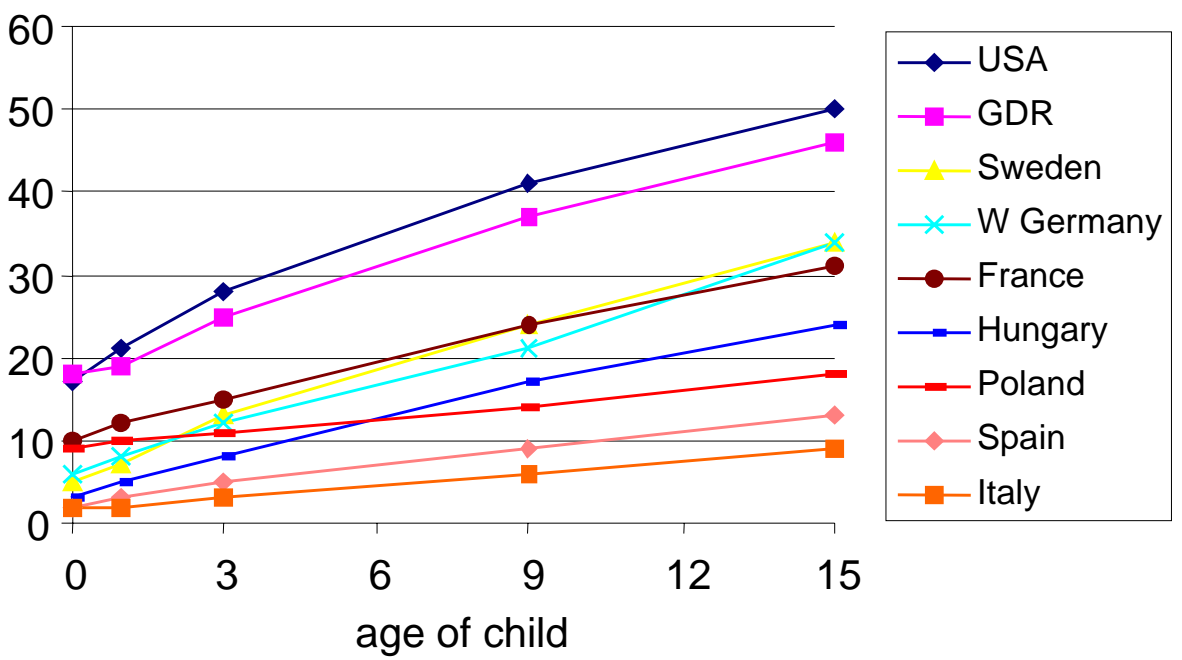

Table 6 and Figure 1 summarizes the information gathered from Tables 2 and 4 in that they report the cumulative percent of all children who ever have the experience of living outside a union of their two parents by the exact ages $0,1,3,9$, and 15 . (Figure 1 displays the results for a select group of countries.) Children who are born to a lone mother enter already at age 0 , i.e., at birth, while children who are born in a union, and then at some point in time experience a union dissolution of their parents, subsequently add to this initial fraction of children. The high proportion of births to a lone mother in the USA and the former GDR (Table 2) shows up in the first column of Table 6 . The last column of the same table shows that the USA has the highest proportion of children, as much as 50 percent, with any experience of living outside a two-parent family when they turn 15 . The USA is closely followed by the GDR and Latvia, while in many Western and Eastern European countries it is more common to find that around a fourth or a third of all children have an experience of that kind, at some time during childhood. A number of Catholic countries in various parts of Europe again stand out with lower levels than the average. Flanders, Spain, Slovenia, and Poland all have proportions below 20 percent and in Italy, only nine percent of all children ever have such an experience. 
Table 6: $\quad$ Cumulative percent ever out of union, by exact age of child

\begin{tabular}{llrrrrr} 
country & period & at birth & age 1 & age 3 & age 9 & age 15 \\
\hline Sweden & $(1987-93)$ & 5 & 7 & 13 & 24 & 34 \\
Norway & $(1983-89)$ & 7 & 9 & 13 & 21 & 26 \\
Finland & $(1983-89)$ & 3 & 4 & 8 & 16 & 22 \\
France & $(1988-94)$ & 10 & 12 & 15 & 24 & 31 \\
USA & $(1989-95)$ & 17 & 21 & 28 & 41 & 50 \\
Austria & $(1990-96)$ & 10 & 12 & 15 & 26 & 34 \\
W Germany & $(1986-92)$ & 6 & 8 & 12 & 21 & 34 \\
Flanders & $(1985-92)$ & 1 & 2 & 4 & 11 & 17 \\
Italy & $(1990-95)$ & 2 & 2 & 3 & 6 & 9 \\
Spain & $(1989-95)$ & 2 & 3 & 5 & 9 & 13 \\
GDR & $(1984-89)$ & 18 & 19 & 25 & 37 & 46 \\
Hungary & $(1988-93)$ & 3 & 5 & 8 & 17 & 24 \\
Czech Rep & $(1992-97)$ & 4 & 6 & 11 & 20 & 29 \\
Slovenia & $(1989-95)$ & 6 & 7 & 8 & 12 & 15 \\
Latvia & $(1989-95)$ & 11 & 15 & 22 & 35 & 44 \\
Lithuania & $(1989-95)$ & 5 & 7 & 10 & 20 & 29 \\
Poland & $(1986-91)$ & 9 & 10 & 11 & 14 & 18 \\
\hline
\end{tabular}

The estimates pertain to synthetic cohorts experiencing the transition rates prevailing six years prior to the survey date

\section{3e. Children's experience of family reconstitution}

In Table 7, we demonstrate what happens to children who experience their parents' union disruption. We describe to what extent they again find themselves living in a union with their mother and a new partner of hers by durations of exactly $1,3,6$, and 10 years after the family breakup. High levels of entry into a stepfamily of children who have experienced a parental separation are found in the USA, the GDR, and the Czech Republic. In the two East European countries, around 30 percent of such children live in a new family already one year after the family breakup. Two thirds of such children in the three countries mentioned above have had the experience of living in a stepfamily at a duration of six years from the family dissolution. In many cases, countries with a relatively high level of disruption rates of child-families also exhibit higher levels of formation of new 
stepfamilies than other countries do. The lowest propensities of children to enter a new two-parent family are found in Italy and Poland. A calculation of mean values of the durations when children enter a stepfamily, calculated for the children who have had such an experience (not shown here), reveals that this event, on the average, takes place around 3-4 years after the dissolution of the parental union.

Table 7: Cumulative percent ever again in a union, by time since union disruption, for children experiencing parental separation

\begin{tabular}{llrrrr} 
country & period & 1 year & $\begin{array}{c}\text { duration } \\
\text { 3 years }\end{array}$ & 6 years & 10 years \\
\hline Sweden & $(1987-93)$ & 11 & 32 & 51 & 62 \\
Norway & $(1983-89)$ & 17 & 41 & 57 & -- \\
Finland & $(1983-89)$ & 15 & 31 & 45 & 64 \\
France & $(1988-94)$ & 10 & 23 & 35 & 47 \\
USA & $(1989-95)$ & 21 & 47 & 67 & 78 \\
Austria & $(1990-96)$ & 18 & 30 & 47 & 54 \\
W Germany & $(1986-92)$ & 8 & 29 & 50 & -- \\
Flanders & $(1985-92)$ & 21 & 37 & 54 & -- \\
Italy & $(1990-95)$ & 2 & 8 & 28 & -- \\
Spain & $(1989-95)$ & 5 & 25 & 37 & 47 \\
GDR & $(1984-89)$ & 28 & 55 & 65 & -- \\
Hungary & $(1988-93)$ & 15 & 39 & 57 & 68 \\
Czech Rep & $(1992-97)$ & 32 & 61 & 71 & 77 \\
Slovenia & $(1989-95)$ & 14 & 36 & 62 & 71 \\
Latvia & $(1989-95)$ & 16 & 32 & 43 & 60 \\
Lithuania & $(1989-95)$ & 9 & 25 & 43 & 57 \\
Poland & $(1986-91)$ & 7 & 19 & 25 & 38 \\
\hline
\end{tabular}

The estimates pertain to synthetic cohorts experiencing the transition rates prevailing six years prior to the survey date 


\section{3f. A summary measure of children's experience of living in different types of families}

We conclude our presentation with a crude summary of the fractions of time that respondents' children spent in various family types (Table 8 ). These percentages have simply been calculated from the family states that mothers reported for their children during the six-year period that came immediately prior to the interview date. We distinguish between time spent with a lone mother (with time spent after a family disruption and time spent immediately after childbirth given separately) and time that occurred after a child left its mother in order to live on its own or with someone else (Note 1). We also report the proportions of childhood experience with the original parents living in a consensual union and in a marriage, respectively. Finally, we report the percentages of time that refer to children in a stepfamily. All summaries cover the experience of children aged 0-14 (Note 6).

As we might expect, we find the highest proportion of children living with a lone mother, or not with a mother at all, in the USA. On average, as much as 22 percent of children here live in a one-parent family (or in any family without their mother). Common averages for children in Europe stand, rather, at around 10 percent of childhood time in such families. Latvia is found at the top with a figure of 15 percent while children in Flanders, Slovenia, Spain, and Italy only contribute 3-6 percent of their childhood to the one-parent family type. The USA also stands out as the country where it is most common for children to live in a stepfamily; 10 percent of all childhood time there is accountable to that family type. In Europe, on the other hand, it is common to find that around 5 percent of childhood time belong to stepfamilies. The highest levels are recorded for children in the GDR, the Czech Republic, and Latvia (7-8 percent), while the lowest values are found for children in Italy, Spain, Slovenia, and Poland (0-2 percent).

A final conclusion from Table 8 is that the vast majority of children live with both their original parents. The reported time that is attributable to this type of family is much lower for children in the USA than in any European country, but even in the US we find that 67 percent of all childhood time refers to periods when children live with their two original parents. In Europe, this value ranges from a minimum of 79 percent in the former GDR and Latvia to a maximum of 97 percent for children in Italy. We can also see that practically all children who live with their

original parents live in matrimony. Evidently, it is only in Sweden where it is very common for children to live with two cohabiting but not married parents: 17 percent of all childhood time there is spent in such families. It is interesting to note that the USA and Sweden have exactly the same low proportion of childhood time accountable to periods when children live with their two original parents in 
marriage. The big difference is that in Sweden, most of the remaining children live with their original parents in a consensual-union family, while in the USA they live, rather, with a lone mother or in a stepfamily.

Table 8: $\quad$ Percent of time spent in different family types at ages 0-14 years

\begin{tabular}{|c|c|c|c|c|c|c|c|c|c|}
\hline country & period & time with lo & $\begin{array}{l}\text { - after } \\
\text { disruption }\end{array}$ & $\begin{array}{l}\begin{array}{l}\text { with no } \\
\text { mother }\end{array} \\
\text { (Note 1) }\end{array}$ & $\begin{array}{l}==>\text { total } \\
\text { lone/no } \mathrm{m} .\end{array}$ & $\begin{array}{l}\text { cohabita- } \\
\text { tion }\end{array}$ & oth parents & $\begin{array}{l}==>\text { total } \\
\text { both } \\
\text { parents }\end{array}$ & $\mid \begin{array}{l}\text { time in } \\
\text { step } \\
\text { family: } \\
\text { (with } \\
\text { mother) }\end{array}$ \\
\hline Sweden & $(1987-93)$ & 2 & 9 & 2 & 12 & 17 & 64 & 81 & 6 \\
\hline Norway & $(1983-89)$ & 2 & 5 & 0 & 7 & 5 & 84 & 89 & 4 \\
\hline Finland & (1983-89) & 1 & 6 & 1 & 8 & 4 & 84 & 88 & 4 \\
\hline France & $(1988-94)$ & 4 & 7 & 0 & 11 & 8 & 78 & 86 & 3 \\
\hline USA & $(1989-95)$ & 7 & 13 & 2 & 22 & 4 & 64 & 67 & 10 \\
\hline Austria & $(1990-96)$ & 4 & 8 & 1 & 12 & 6 & 79 & 84 & 4 \\
\hline W Germany & $(1986-92)$ & 2 & 8 & 1 & 12 & 5 & 78 & 83 & 5 \\
\hline Flanders & $(1985-92)$ & 0 & 4 & 0 & 5 & 1 & 91 & 92 & 3 \\
\hline Italy & $(1990-95)$ & 0 & 2 & 0 & 3 & 1 & 95 & 97 & 0 \\
\hline Spain & $(1989-95)$ & 1 & 3 & 0 & 4 & 1 & 93 & 94 & 1 \\
\hline GDR & $(1984-89)$ & 5 & 8 & 1 & 13 & 6 & 73 & 79 & 8 \\
\hline Hungary & $(1988-93)$ & 1 & 6 & 0 & 8 & 2 & 86 & 87 & 5 \\
\hline Czech Rep & $(1992-97)$ & 1 & 6 & 0 & 8 & 2 & 84 & 85 & 7 \\
\hline Slovenia & (1989-95) & 2 & 3 & 1 & 6 & 6 & 86 & 92 & 2 \\
\hline Latvia & (1989-95) & 3 & 11 & 0 & 15 & 3 & 75 & 79 & 7 \\
\hline Lithuania & (1989-95) & 2 & 8 & 0 & 10 & 1 & 85 & 86 & 3 \\
\hline Poland & $(1986-91)$ & 5 & 3 & 0 & 9 & 1 & 90 & 90 & 1 \\
\hline
\end{tabular}




\section{Conclusions}

Our presentation has revealed both striking differences and strong similarities between countries when it concerns patterns of family-demographic affairs of children. The USA stands out as an extreme case with its very high proportion of children born to a lone mother, with a higher probability that children experience a union disruption of their parents than anywhere else, and with many children having the experience of living in a stepfamily. Italy stands out at the other end of the scale. Practically all children here are born to a married mother and very few of them experience dissolution of their parents' union before they turn 15 . The vast majority of children in Europe are born in a union and spend their entire childhood living with both of their original parents. The differences in family conditions between children in the USA and children in Europe, is impressive but important variation also exist between countries in Europe. Our study covers the family-demographic situation in a relatively large number of countries in Europe, from both sides of the former Iron Curtain. We do not find any systematic differences between countries in Eastern Europe and countries in Western Europe but rather a variation between countries within each sphere of the continent. Some European countries are characterised by particularly stable family patterns from the point of view of children. These countries are found in different areas of Europe but all have the trait in common of being strongly dominated by the Catholic confession. European countries with a higher degree of volatility in their family-demographic affairs are all characterised by a less influential role of religion in general and of Catholicism in particular. With the exception of Sweden, it is not really common for children to grow up in families with cohabiting but not married parents. Children born in cohabitation are exposed to higher disruption risks than children born in marriage, so the general level of child-family disruption is also related to the level of childbearing to cohabiting couples.

To conclude, we believe that our cross-country comparison has provided a lucid overview of the actual family-demographic situation of children in Europe and the US - and of existing differentials and similarities in patterns between countries. We found it particularly valuable to be able to include a number of East European countries into our picture so that we could compare the situation in these countries with the situation in Western Europe. Our study of Eastern Europe mainly covers the period around or just after the transition from the former situation of state socialism there. For the future, we recommend that descriptive measures of the kind we have presented here, should be applied also to other demographic sources so that we can derive comparable information from yet further countries - and time periods. It would be interesting to involve even more East European countries in our 
picture, in particular Russia and the various successor states of the former Soviet Union. In addition, it would be interesting to include Britain and further AngloSaxon countries into our cross-country comparison.

\section{Acknowledgments}

I am grateful to Dimiter Philipov for his cooperation in the production of the various life tables that have served as the basis for this paper. I am grateful for advice from Jan Hoem, Larry Bumpass, Ron Lesthaeghe, and Kathleen Kiernan on the setting up of our system of life tables (presented in Andersson and Philipov 2002). I thank the Advisory Group of the FFS programme of comparative research for its permission, granted under identification number 75, to use the original FFS data on which this study is based. In addition, I am grateful to the Stockholm University Demography Unit for its permission to use the cleaned version of the Swedish FFS. Finally, I thank Yvonne Sandor for her linguistic checking of my text. 


\section{Notes}

1. The proportions of childhood spent in families where the mother is not present are generally very low and can actually be disregarded. They amount to a maximum of two percent in the USA and Sweden, and even less than that in the other countries considered. For Lithuania and Poland, we have no information on children's actual living arrangements, so here we assume that they continue to live with their mother in the case of, for example, a family disruption. For Norway, we know if a child has left its mother but we have no information about the date of that event so we choose to exclude such children completely from our calculations. For France, we cannot distinguish if a child has died or moved away from its mother, and here we censor our observation at the point when such an event occurs. In summaries, as in Table 8, these four countries thus show up with 0 percent of children living away from their mother, a feature that they actually share with many countries where we indeed have the full information on the residential histories of children.

2. Each life table is based on the probabilities that a child at age $x$ moves from a specific family-demographic state to another state of interest by exact age $x+1$. The probabilities are calculated from all reported events of a specific kind, by age, and all recorded months of exposure to that event, by age, during our study period.

3. The FFS data from the Netherlands are not available to researchers outside that country. Data from Bulgaria and Portugal do not contain union histories of respondents and cannot be used for calculations like ours.

4. The Belgian FFS only covers the Flemish-speaking parts of the country.

5. The surveys conducted in the Czech Republic, Norway, Slovenia, Sweden, and the USA cover female respondents up to an age of around 45 years. The surveys in Finland, France, Italy, Latvia, Lithuania, Poland, and Spain include respondents aged up to around 50 years. The Austrian FFS deviates in including respondents as old as 54-55 years, while those of Flanders, Germany, and Hungary only include respondents up to approximately age 40.

6. Each age group of children have the same weight when we perform our summation so that our summary measure is not affected by the current age distribution of respondents' children. The summary is otherwise made directly from the distribution of children over family states as reported by their mothers for the calendar period we study. They are not based on any type of incrementdecrement life-table analysis. 


\section{References}

Alt, C., 2001. Kindheit in Ost und West: Wandel der Familialen Lebensformen aus Kindersicht. Leske+Budrich, Opladen, Germany.

Andersson, G., and Philipov, D., 2002. "Life-table representations of family dynamics in Sweden, Hungary, and 14 other FFS countries: A project of descriptions of demographic behavior". Demographic Research [Online] 7: 67-270. Available http://www.demographic-research.org/Volumes/Vol7/4.

Bumpass, L., and Hsien-Hen Lu, 2000. "Trends in cohabitation and implications for children's family contexts in the United States". Population Studies 54: 29-41.

Bumpass, L., and Raley, K., 1995. "Redefining single-parent families: Cohabitation and changing family reality". Demography 32: 97-109.

Dennis, M., 1999. "The East German family: Change and continuity". In Flockton, I., et al. (eds), Recasting East Germany: Social Transformation after the GDR: 83-101. Frank Cass, London.

Heuveline, P., and Timberlake, J., 2000. "Towards a child-centered life course perspective on family structures: Multi-state early life tables using FFS data". Paper presented at the FFS Flagship Conference, Brussels, 29-31 May 2000 .

Heuveline, P., Timberlake, J., and Furstenberg, F., 2001. "An international comparison of children's experience of family structure". Paper presented at the IUSSP XXIV General Population Conference, Salvador, Brazil, 18-24 August 2001.

Kiernan, K., 2000. "The state of European unions: An analysis of FFS data on partnership formation and dissolution". Paper presented at the FFS Flagship Conference, Brussels, 29-31 May 2000.

Kiernan, K., 2001. "The rise of cohabitation and childbearing outside marriage in Western Europe". International Journal of Law, Policy, and the Family 15: $1-21$.

Klijzing, E., and Macura, M., 1997. "Cohabitation and extra-marital childbearing: Early FFS evidence”. International Population Conference, Beijing, 11-17 October 1997, Vol 2: 885-901. IUSSP, Liège, Belgium. 
Murphy, M., 2000. "The evolution of cohabitation in Britain, 1960-95". Population Studies 54: 43-56.

Prinz, C., 1995. Cohabiting, Married or Single: Portraying, Analyzing and Modeling New Living Arrangements in the Changing Societies of Europe. Ashgate Publishing Co, Brookfield, Vermont.

Toulemon, L., 1997. "Cohabitation is here to stay". Population: An English Selection 9: 11-56. 
Demographic Research - Volume 7, Article 7 